\title{
JUSTICE HOLMES: ANOTHER ASPECT OF HIS LIFE AND PHILOSOPHY*
}

\author{
F. HowARD EIDRIDGE $\dagger$
}

$\mathrm{W}$ HEN Pope wrote the line "Just as the twig is bent, so the tree's inclined," he was praising, without qualification, the enduring influence of early education. A more recent writer, with a somewhat different point of view, has said that "the most brilliant intellect is a prisoner within its own social inheritance" and "beyond a certain point can never transcend the limitations" so inherited. This suggests that the more closely an education reflects a distinctive culture, the more likely it is to be a handicap to the attainment of the highest intellectual possibilities.

Undoubtedly both of these propositions are to a large extent true, and the one may find its illustration, and the other its analogue, in a stand of timber, where each of the separate trees appears to have responded in the same degree to the influence of the prevailing winds, and all seem to have been subject to the same limits on upward growth. But even in the case of trees, the seemingly uniform operation of the laws of life and growth is statistically, rather than individually, invariable. There are always some departures from the norm. An occasional seedling, though starting from the same level as its neighbors, nourished by the same soil, and subject to the same impediments and thrusts, will be found, through some innate strength or unique virtue of its own, to have achieved a little more erectness, to have reached a point a little nearer to the sun. Similarly, there are, on occasion, individual men who, although undeniably products of a distinctive environment, have proved less susceptible to its limiting influences than their conventional-minded neighbors, more determined to originate their own speculations and to formulate their own truths, and to that extent have escaped the bondage of their social inheritance and added to their intellectual stature.

Such a person, to a preemminent degree, was the late Justice Oliver Wendell Holmes, and it is with a view to emphasizing that aspect of his life, philosophy, and achievements that this paper has been written.

So we start with Boston, one hundred and two years ago, or on

* Delivered before the Chicago Literary Club on March 8, I943.

$\dagger$ Member of the Chicago Bar. 
March 8, I84I, when there was born to young Doctor Holmes his first child, a son who was given his father's not yet famous name and was destined to carry it to even greater fame than the parent himself was soon to achieve.

Even before Doctor Holmes had established himself as a notable in his own right, his family background gave him an assured place in the social and intellectual life of Boston. In fact, it could hardly be denied to such a personable descendant of a half dozen or more generations in New England of Holmeses, Olivers, and Wendells, who included among their number successive graduates of Harvard or Yale, a Congregational minister and historian who established the first parish of that faith in Cambridge, a captain and surgeon in the French and Indian Wars and the Revolution, a judge or two, a prominent merchant, and a founder of the first bank in New England. If any closer linkage with the leaders of New England culture were needed, Doctor Holmes was also related to such eminents as the Richard Henry Danas, William Ellery Channing, and Wendell Phillips.

That heritage of family traditions and connections would undoubtedly have been a help to one of mediocre talent or modest ambition. But to one otherwise equipped or minded, the settled paths of thought and expected patterns of behavior imposed by such a background might be something less than useful. So thought Henry Adams, born some three years before the junior Holmes and in much the same circumstances. Adams, in the autobiography written towards the end of a life largely warped by just such a heritage, spoke thus of himself, born and christened by his uncle in the shadow of the Boston State House, as a scion of the distinguished Adams and Brooks families:

Had he been born in Jerusalem under the shadow of the Temple and circumcised in the Synagogue by his uncle the high priest, under the name of Israel Cohen, he would scarcely have been more distinctly branded, and not much more heavily handicapped in the races of the coming century, in running for such stakes as the century was to offer; but, on the other hand, the ordinary traveller, who does not enter the field of racing, finds advantage in being, so to speak, ticketed through life, with the safeguards of an old, established traffic. ${ }^{x}$

The distinctive cultural environment in which young Holmes grew to manhood had the same double aspect. From one point of view it was a practical assurance of some degree of intellectual activity and achievement. But because of the very strength and pervasiveness of the fundamental philosophy which it manifested, it might also be regarded as a

I Education of Henry Adams I (I93I). 
powerful force to shape the thoughts and fix the mental horizons of those subjected to its influence.

More than two centuries of common life and effort, facing the same obstacles, sharing the same successes, viewing the same aspects of nature, and cherishing the same fundamental religious beliefs, had inevitably resulted in giving the people of New England not only common traditions, standards, and ideals, but also a substantially similar way of looking at the world and responding to its invitations. And when, in the course of time, their communities had reached a stage of material progress and social achievement sufficient both to sustain and to enjoy the exercise of faculties released from the more imperious demands of self-preservation, their thoughts, feelings, and aspirations found abundant expression.

Scholarship willingly participated in that development. The current offerings of contemporary Europe, together with the storehouse of the ancient classics and the contributions of the Renaissance, were drawn upon to feed the appetite and serve the purposes of the maturing culture. It may not be true to say that none of the importations had an influence in shaping or fixing the direction of New England thought and studies, but the fact does seem to be that by and large the foreign additions were so far assimilated to the domestic views and doctrines that the resulting cultural output remained unmistakably indigenous. In the synthesis of inherited views with the thoughts of other times and places, it was the former and not the latter which retained their essential character and gave the shape and color to the final product. As illustrative of that reaction, there might be cited a remark of Emerson. On returning from his first trip abroad, during which he had visited with Landor in Italy, Coleridge at Highgate, Wordsworth in the Lake Country, and Carlyle at Craigenputtock, Emerson thanked God for having given him that experience and thereby "comforted and confirmed him in his convictions."

In the two decades immediately following the birth of Holmes and preceding the outbreak of our Civil War, this cultural development reached the phase significantly described as "The Flowering of New England." That period saw the rise to literary fame of the most distinguished group of New England writers. There was Emerson, whose first volume of essays was published in I84I, and who probably attained his height with English Traits in 1856 ; Thoreau, whose Walden was published in 1854 ; Lowell whose Biglow Papers was commenced in 1843 and whose Vision of Sir Launfal was published in I848; Hawthorne, whose Scarlet Letter appeared in I85०; Longfellow, whose Ballads first appeared in $184 \mathrm{I}$, followed by Evangeline in $\mathrm{r} 847$, Hiawatha in $\mathrm{r} 855$, and The Courtship of Miles Standish 
in I858; Whittier, whose poems gained their first wide acceptance through the Atlantic Monthly, commencing with its first issue in 1857 ; Prescott, whose Conquest of Mexico was published in I843, and his Conquest of Peru in 1847 ; and, of course, Doctor Holmes himself, who by I860 had become established as a national literary figure through his Autocrat of the Breakfast Table series.

All those writers, as well as numerous others of the period who might be mentioned, were more than mere contemporaries who had nothing further in common except the general point of view they reflected. They had many close ties of association. For the most part they were sponsored by the same publishing house, Ticknor and Fields, of Boston. The Atlantic Monthly, edited by Lowell, was another common bond; its first issue, published in 1857 , contained contributions from Emerson, Holmes, Longfellow, and Whittier. More intimately yet, they had their Saturday Club, dining monthly at the Parker House and consisting largely of the writers already mentioned, together with such other contemporary notables of congenial tastes and views as Asa Gray, the botanist, Agassiz, the geologist, Motley, the historian, Peirce, the mathematician, and Sumner, the statesman. And in the very center of all this intellectual activity and social interchange there could always be found Doctor Holmes. In addition to his own literary eminence, assured social position, and professorship at Harvard, his sympathetic and disarming personality made him the ideal liaison officer between the enthusiasms of Concord, the scholarship of Cambridge, and the amenities of Beacon Hill. Thus it naturally came about that it was Doctor Holmes who named the Atlantic Monthly, celebrated the dinners of the Saturday Club, and gave to the Brahmin caste of Boston its name and its conscious ideals.

If then, as Doctor Holmes once suggested, "nothing that can be taught a growing.mind is like the atmospheric knowledge he breathes from his infancy onwards," it is certain that the doctor's son was saturated with the cultural exhalations of the Boston of his youth. Furthermore, the same intellectual sustenance was fed to him in more tangible form as his formal schooling proceeded. Like most other boys of his acquaintance, he received his scholastic education at Mister Dixwell's Latin School, and then, as tradition commanded, went on to Harvard. To borrow a term of current fashion, his "indoctrination" in New England culture was complete.

To Henry Adams, who preceded young Holmes by three years in an identical program of education, the knowledge thus acquired was of trifling value to one who was to face the needs of the twentieth century. In his autobiography he frequently refers to it in criticism or disparagement, 
and there is more than a suggestion that his own life would have been a greater success had the courses been other than they were at the Latin School and Harvard.

It is doubtless true that what Adams said in this connection was quite as much a reflection on himself as on the educational institutions to which he referred. But there is at least this much to be said in support of his criticism of the scholastic curriculum then offered to the youth of Boston: By its concentration on the languages and literature of the ancient classics it may have laid its foundations broad and deep in the wisdom of the past, but there were not many students capable of completing a useful structure of knowledge upon a scale so spacious. Moreover, although it accurately reflected the traditions and ideals of the culture which it sought to express and serve, it tended, by that very circumstance, to close the mind to the possibility that other standards and values might be accepted and prevail, even in the near future and among intelligent men.

Such then was the environment in which the future Supreme Court Justice was born, raised, and schooled. But what was the human material upon which there were impressed the forces and influences we have described? And what were the developments that preceded the emergence of the venerable figure with whom this generation was acquainted?

First of all, he was born an aristocrat, but for the reasons and in the sense that Doctor Holmes expressed when he stated that an aristocracy was being formed in this country "not a gratia-Dei, nor a jure-divino one, -but a de facto upper stratum of being," based on the advantages resulting from the possession of money for several generations. For as the doctor said, "Money buys air and sunshine, in which children grow up more kindly, of course, than in close, back streets; it buys country-places to give them happy and healthy summers, good nurses, good doctoring, and the best cuts of beef and mutton." And you may be sure that Doctor Holmes was writing then, not in envy, but in pleasant regard to the happy situation of himself and his growing family. By the time Wendell, Junior, was eight years old, even the place in the country had been acquired, a summer house built on land for generations in the family, high in the Berkshires between Lenox and Pittsfield. There for many years the family summers were spent in lively outdoor activities. Nor was Boston wholly without recreational facilities for those in comfortable circumstances. In addition to the conventional school and playground games, there was boating on the green waters of the Back Bay, and a tramp in the woods to enjoy the chemistry of spring or fall was a time-honored pastime not too difficult of accomplishment. 
Thus, when we look at a photograph of young Wendell, at the age of twenty, we see a strong and vital figure, erect, slender but well formed, and tall, a proof of the physical advantages of his heritage and upbringing, and a promise of the long and vigorous life that was still before him. Studying the picture more closely, some qualities of mind and will are also apparent, but what they indicate for the future is a little more difficult to discern. Certainly the young man is handsome-strong, well-chiselled features, a high but not protruding forehead balanced by an abundant head of hair, deep-set, rather searching, eyes, a generous but firm mouth with just a hint of humor and vivacity in the slight upward turn of its corners, and something more than a hint of strength of character in the set of the chin and the long sloping line of the jaw. A young man of obvious intelligence and force of character, but in just what occupation those qualities would be utilized, it would have been hard to prophesy. The eyes were searching, indeed, but they mirrored as well a questioning mind that sought beyond the immediate object of vision. Poise and balance were manifest, with their warrant of sound practical judgment in the ordinary affairs of life, and yet there was something in his expression, as well as in his cast of countenance, that indicated one who would wish to meet life and translate it in terms of high ideals.

The truth is that at the time the picture was taken the young man had just graduated from college and had not yet fully settled in his own mind what he proposed to make of his life. He had a feeling for the arts, as evidenced not only by an early enthusiasm for Ruskin, but also by many discerning references and metaphors in his utterances of later life. He even, in his youth, made some study of art and went so far as to produce a few etchings. But it is doubtful whether he ever intended to concentrate on that pursuit. What really appears to have seized his mind when he was in college, and to have suggested itself to him as a possible life work, was the study of philosophy, in the specific sense of the ultimates of human thought and existence. It is true that he appears to have devoted himself assiduously to all his college studies, as shown by the fact that he gained an affection for the ancient writers and an ability to read them in the originals, as well as a sound working knowledge of French and German that stayed with him all his life. But it is obvious that it was the ultimates of philosophy that aroused his deepest interest. Whether this was due to the natural development of an inquiring mind, to the inspiration of Emerson, for whom he had not only a youthful admiration but also a personal affection which did not diminish through the years, or whether the explanation lies in some particularly stimulating associations at Harvard, may 
be debatable. It is a fact, however, that when young Holmes was completing his collegiate work at Harvard he felt that his future lay in some field of activity, presumably of a scholarly type, that would, in his words, "furnish philosophical food to a philosophical mind." The particulars of that future occupation remained to be determined, and, although he was considering, without enthusiasm, the possibility of going on to law school, he was far from certain that he would choose the law as a career. However, as events turned out, it would be three years before a definite decision had to be made, and the experience of those years would then contribute much to that decision.

For on April I2, I86r, the first shot of the Civil War was fired and on July Io, I86I, when the commencement exercises of the Class of I86I were held, the Class Poet, Oliver Wendell Holmes, Jr., although able to be present to read his poem, had already enlisted in the Massachusetts Volunteer Infantry. His decision to enlist in the Union forces was not the result of a momentary enthusiasm, nor to satisfy a youthful desire for romantic glory. The issues being what they were, it was the only thing a person of his character could do. He came from a communitywhich believed that the Union was the guaranty of the liberties for which their ancestors had fought and as such should be preserved. It was a community, moreover, which had with increasing fervor given eloquent words to the belief that human slavery was a degrading evil that should be abolished. Holmes shared both those beliefs, and to him, as frequently expressed throughout his life, the sole test of a belief is the willingness to fight for it, and the value of life is heightened by the opportunity of risking or even sacrificing it for great ideals.

It was not long after young Holmes enlisted that he found himself not only in active service but in the thick of battle. In August, I86I, four months after his enlistment, he received a commission as First Lieutenant in the Twentieth Massachusetts Regiment. On September 4 the regiment proceeded to Washington. On September $\mathrm{I}_{4}$ they took a position near Leesburg, Virginia. On October 2I they were in battle at Balls Bluff.

It was not much of a battle compared to other engagements of that war, but of some seventeen hundred Union men who participated in it, and practically none of whom had been under fire before, fully a thousand were killed, wounded, or captured. Among the wounded was Lieutenant Holmes. A bullet had entered his left breast, missed his heart by a narrow margin, and exited from his right side. He was carried from the field unconscious.

The wounds, at first thought to be mortal, proved somewhat less seri- 
ous. In a few days he was moved to a hospital at Philadelphia, and shortly thereafter brought back to Boston by Doctor Holmes. His convalescence, though slow, was uneventful, and by the following March he was back with his regiment.

Shortly after his return he was promoted to Captain, and not long after that the Twentieth Massachusetts was again in action. In April, I862, it was sent south to the neighborhood of Yorktown, Virginia, to support one of the earlier efforts to capture Richmond. There it participated in the battle of Fair Oaks or Seven Pines, the fighting about the Chickahominy and the Seven Days Battle which ended on July I with the bloody engagement of Malvern Hill. Although the fighting during that period was fierce and continuous and Captain Holmes was in the midst of it throughout, he came through unscathed. But this good fortune did not last long.

In September the Twentieth Massachusetts was moved north to join the forces assembled to meet General Lee's thrust into Maryland and Pennsylvania. Before the month was out there came Antietam, and among the many casualties was Captain Holmes, with a bullet through his neck. As before, Doctor Holmes was prompt to respond to the notification that his son was wounded. In his subsequent story, "My Hunt for the Captain," the doctor tells of the search he made among the hospitals and other possible havens of the wounded, until at last the captain was found on a hospital train pulling out of Hagerstown.

There ensued a second convalescence in Boston, but more brief than the first. By December Captain Holmes was back with his regiment in the battles of the Rappahannock at Fredericksburg. Here the Union forces facing Lee had an initial success which was soon turned into an almost disastrous defeat, losing more than I4,000 men. This time Captain Holmes was not among the casualties, if you can except dysentery, which forced him to spend some time in the military hospital.

Six months later, in May, $186_{3}$, the Twentieth Massachusetts was again at the Rappahannock, facing Fredericksburg, under orders to take the town and move on to Chancellorsville. In the ensuing battle, Captain Holmes received his third serious wound. A piece of shrapnel struck and splintered his heel, breaking off part of the bone and exposing much of the remainder.

There was a third period of convalescence in Boston, followed again by a return to active service as an aide-de-camp to a divisional commander of the Army of the Potomac from January, I864, until the following July, when the war was over and Holmes was mustered out of service with the brevet rank of Lieutenant Colonel. 
Now there are many persons to whom a war experience such as the one just recounted, or indeed one much less eventful, would be overwhelming in its effect. There is the familiar type to whom the excitement of having participated in such stirring events, or of having been, if only by virtue of a military uniform, the object of public admiration and attention, so far surpasses any subsequent possibilities of his life that he can never thereafter think of himself, or permit himself to be regarded, other than with reference to his previous war experience. Such a person puts aside the cap of the soldier only to replace it with the wreath of the veteran, and spends the rest of his life in reluctant descent from the high point he reached in his youth. There is another type to whom the ugly facts of war seem so horrible or depressing that he never succeeds in repairing the damage they have done to his mind or character. And, of course, there is the type who endlessly seeks to exploit whatever merit he can claim for the fact or circumstances of his military service.

The war had no such effect on young Holmes. Rather than representing to him his ultimate achievement, it sharpened his appetite for life and strengthened his determination to use it to the full to accomplish the most complete realization of his possibilities. He was more than anxious to have his try at succeeding in some activity in which he could do his best. As he wrote his friend, Sir Frederick Pollock, many years later: "The real anguish is never to have your opportunity. I used to think of that a good deal during the war." Nor did his war experiences, grim as some of them were, prey upon his mind or give a psychopathic twist to his character. On the contrary, with a full appreciation of the horrors and miseries he had witnessed, he found in the courage that could be summoned to face them, and in the heroism that could rise to surmount them, the inspiring conviction that "man has in him that unspeakable somewhat which renders him capable of miracles, able to lift himself by the might of his own soul, unaided, able to face annihilation for a blind belief." And as to exploiting his war services in after years, not only did he fail to do so, but the very idea would have been repugnant to his nature.

Thus the young man who had indefinite aspirations of making.his name, or at least satisfying his soul, in the realms of philosophy, used the unlikely experiences of war to add to his philosophic education and, incidentally, to aid him in reaching a personal decision. Mere speculative thought, he was now prepared to conclude, is not the fullest use of one's faculties, if one is deeply interested in the passions, hopes, and triumphs of man, which are the very stuff of life. On the other hand, he was convinced that he was an "internal man," one to whom "ideas are more interesting than things," 
and therefore he must choose for himself some pursuit which would reconcile these two compelling considerations.

If his decision had not in fact been reached by the time the war was over, it was soon to follow. On July $I 7$, 1864 , he was given his discharge from the Army. In September he was enrolled in the Harvard Law School and had definitely chosen the law as a career.

In finally making that choice he was not repudiating his earlier aspirations towards a life devoted to the study of philosophy. For in the law, as he then concluded that it might be studied and applied, he could integrate his desire to reach the high plateau of philosophical knowledge and his equally strong desire to live fully, and to exercise his powers to the utmost in contact with the realities, ideals, and struggles of human life.

That the law would serve as a means of attaining philosophic knowledge he was certain because, as he afterwards expressed it:

All that life offers any man from which to start his thinking or his striving is a fact. And if this universe is one universe, if it is so far thinkable that you can pass in reason from one part of it to another, it does not matter very much what that fact is. For every fact leads to every other by the path of the air..... If your subject is law, the roads are plain to anthropology, the science of man, to political economy, the theory of legislation, ethics, and thus by several paths to your final view of life. ${ }^{2}$

And for anyone who so regards the profession of law, Holmes also said:

For him every text that he deciphers, every doubt that he resolves, adds a new feature to the unfolding panorama of man's destiny upon this earth. Nor will his task be done until, by the farthest stretch of human imagination, he has seen as with his eyes the birth and growth of society, and by the farthest stretch of reason he has understood the philosophy of its being. ${ }^{3}$

Accordingly, when Holmes entered law school it was not merely to round out his academic education, or for the purpose of obtaining qualifcations for the practice of a profession which would furnish him with the means of maintaining a respectable position in the comfortable world that was waiting to receive him. It was also, and more importantly, intended to be a door through which he could realize the utmost possibilities of his character.

This does not mean that he felt himself above the practical aspects of his chosen profession. Upon his graduation from law school in 1866 , he began his apprenticeship as a lawyer in the office of a relative, Robert $M$. Morse. Then there was a brief period of practice with his younger brother, Edward Jackson Holmes, followed by an association with the firm of Chandler, Shattuck, and Thayer, and finally the partnership of Shattuck,

${ }^{2}$ Holmes, Collected Legal Papers 30 (1920).

3 Tbid., at 27. 
Holmes, and Munroe, which continued until Holmes was appointed to the Massachusetts Supreme Court in I882. Thus his views on the type of problems met in the actual practice of law were based on something more than academic assumptions, and his judgments reflected the previous discipline of having been subject to the responsibility of making up his mind on legal questions, at his peril, for purposes of action. But that practical experience, valuable as it may have been, was not the most significant aspect of the years which preceded his appointment to the bench.

When Holmes graduated from law school, although he had worked hard, enjoyed his associations there, and was grateful to his professors for what they had taught him, he knew that for him, in an even truer sense than for an ordinary graduate, his education had only commenced. For what he had learned in nowise satisfied his mind or met his aspirations. The law, as then formulated, "presented itself as a ragbag of details." So regarded, it might, if meticulously learned, suffice for one who sought only to be equipped to deal on equal terms with his professional contemporaries. But to one who also wanted to find in it "philosophical food for a philosophical mind," that view of the law was utterly inadequate. It was not enough for him to know what the established law was. What he wanted, in addition, was, as he put it, "an understanding of how the law came to be what it is, of its broadest generalizations, and . . . of the reasons to be offered for continuing it in its present form or for desiring a change." 4

Under the circumstances then existing, this proved to be an objective of extraordinary difficulty. It set up goals which, as it soon became evident, could not be reached, or even measurably approached, except along paths that, so far as he could determine, had not even been surveyed. But without such an objective he questioned whether the study of the law was "worthy of the interest of an intelligent man," and it was his determination that he would prove it so. In that resolve he set about doing such work in the law as would exercise his faculties to the utmost, yield the intellectual satisfactions which he wanted, and produce, moreover, fruits which he tremblingly hoped the world would be the better for having.

Accordingly, the period of fifteen years between his admission to the bar and his elevation to the bench was one of unremitting study, almost incredibly superimposed upon his activities as a practicing lawyer. As to the first few years, occasional remarks in letters to or from his friends give us glimpses of how intensely he worked. He writes his intimate, William James, in the winter of $I 867$ that he had enjoyed some months of philosophic debauchery, but that "now it is law-law-law." The following spring

4 Thid., at 302 . 
he mentions that philosophy has been hibernating while he has been immersed in the law. As time went on, further letters from James, and comments by others, reflect real worry that young Holmes is working too hard.

Soon the results of this devotion to his legal studies began to appear. In I870 Holmes was made editor of the American Law Review, which was followed by articles, book reviews, and comments on cases, signed or otherwise identifiable as his, and extending from broad questions of jurisprudence, or the effect of emergent changes in social conditions, to narrow details of practice. In 1870 Holmes was also appointed instructor of constitutional law in Harvard Law School, and he continued his connection with the school until his first judicial appointment in 1882 . In I873 he appeared as the editor of the twelfth edition of Kent's Commentaries on American Law, which represented more than three years of previous preparation to the end that his notes to the text would properly reflect every applicable decision in the United States or England during the twenty-five years since the work was originally written.

Thus by 1873 Holmes had already shown his capacity, as well as his determination, to master the detailed materials of his profession. In addition, although the full force of his originality was not yet disclosed, it was apparent from his writings in the American Law Review that something more than just another conventional legal scholar was in the making. Some years later he was to say: "The mark of the master is, that facts which before lay scattered in an inorganic mass, when he shoots through them the magnetic current of his thought, leap into an organic order, and live and bear fruit." Something like that was now taking place in the "ragbag of details" of the law which he was organizing and animating with the power of his own mind. But the process was not yet fully completed. More material was to be gathered, more thinking was required.

His bachelor's "garret," a room arranged for his studies on the top floor of his father's Beacon Street home, had now been succeeded by a modest apartment above a drugstore near the Athenaeum and shared with his bride, Fannie Bowditch Dixwell (the daughter of his old Latin School principal), whom he married in 1872 . His private practice was beginning to take up most of his days, leaving only the nights for his studies. But these continued.

By that time, so far at least as his legal researches were concernedand they included related work in science, economics, history, and philos'ophy-Holmes had gone beyond the point where he could find the encour-

5 Tbid, at 37 . 
agement or comfort of working together with other congenial minds. But his earlier work had given him some assurance that he was moving in the right direction and that out of the darkness he would eventually come "to daylight and a worthy end." In after years he frequently referred to this period and spoke of the loneliness of the original thinker, who, like the arctic explorer, pushes on alone, leaving behind the companions with whom he started his exploration, and having nothing to assure him beyond a slight indication that he is travelling in the right direction.

"In the first stage one has companions," Holmes said, "cold and black though it be, and if he sticks to it, he finds at last that there is a drift as was foretold. When he has found that, he has learned the first part of his lesson, that one is safe in trusting to courage and to time. But he has not yet learned all. So far his trials have been those of his companions. But if he is a man of high ambitions he must leave even his fellow-adventurers and go forth into a deeper solitude and greater trials. He must start for the pole. In plain words he must face the loneliness of original work. No one can cut out new paths in company. He does that alone."6

Alone, then, Holmes spent the next ten years of his explorations of the law, seeking the explanations of what other men were disposed to accept as a matter of course, or, if they philosophized at all, on the basis of conclusions dictated by the habits of thought in which they had been trained. And, a little at a time, as his own views began to take shape, occasional articles setting them forth were published in the American Law Review, more often than not unsigned, and they were further reflected, more obliquely, in book reviews and current comments which he contributed during that period. But these were only the prolegomena to a more complete exposition. In the winter of $\mathrm{I} 880$ Holmes delivered a series of lectures at the Lowell Institute, in Boston. By February 8, I88I, just before his fortieth birthday, the material of those lectures, considerably amplified, was published in a four hundred page volume entitled The Common Law.

In that treatise Holmes set forth, with the utmost simplicity and clarity, the conclusions he had reached after nearly fifteen years of research and thought regarding the nature and sources of the fundamental legal concepts in our system of law, and the actual processes by which they had been developed and were applied. His approach was historical, but without seeking to fit the facts of history into the mould of a preconceived theory. It was analyical, but also without pushing logic beyond the permissible limits of the actual facts.

${ }^{6}$ Ibid., at 165 . 
In the opening paragraph his general conclusions were stated in a few sentences that have now become classic:

The life of the law has not been logic; it has been experience. The felt necessities of the time, the prevalent moral and political theories, intuitions of public policy, avowed or unconscious, even the prejudices which judges share with their fellowmen, have had a good deal more to do than the syllogism in determining the rules by which men should be governed. The law embodies the story of a nation's development through many centuries. .... In order to know what it is, we must know what it has been and what it tends to become. .... The substance of law at any given time pretty nearly corresponds, so far as it goes, with what is then understood to be convenient; but its form and machinery, and the degree to which it is able to work out its results, depend very much upon its past. 7

But the treatise was not a mere statement of generalities. Holmes established his conclusions by a detailed examination of the actual origin and development in our law of such concepts and theories as those of personal liability, the protection of possession and ownership, the enforceability of contracts, and the succession to the rights of another person. The existing law on those subjects was shown to be fully understandable only if it were recognized to be a phase in a process of continuous growth, and its origin and course of development closely studied. And in considering that development in specific instances, it was shown that old rules often survived for new reasons, which subtly changed the scope and application of the original, and that sometimes the old rule survived as a vestigial remnant of past history without any present reason to support it. Correspondingly, it was shown that the courts often must and do legislate, in the sense of making and changing the law, so that consideration must be given to the necessity, and to the permissible occasions and limits, of that aspect of the judicial function.

But it is needless to go further into the substance of what Holmes presented in his Common Law. Nor is it necessary for our purposes to attempt to trace its influence upon subsequent legal and historical studies. For many of the ideas which it expressed, although novel then, are now so well recognized as to appear commonplace, while the full extent of their influ: ence, particularly as embodied in subsequent judicial opinions of the author, cannot yet be adequately measured. All that we are interested in showing here is that the attitude of Holmes towards the current explanations of legal doctrines, and the manner in which he sought to find his own answers, as well as the conclusions that he reached, indicated not only his innate intellectual capacity but also the extent of his ability to free him-

7 Holmes, The Common Law I (188I). 
self from the prepossessions and habits of thought of his own environment.

It is indeed true that a broad philosophic approach was congenial to the New England mind of that period, and that the example of German scholarship, with its emphasis upon the meticulous study of original sources, was already an influence in Harvard College. But the philosophy that was taught to Holmes was one that tended to seek its ultimate explanations of life in the purposeful pulls of final causes and to view the course of history as the dramatic vindication of accepted moral principles; whereas the underlying philosophy which Holmes adopted found the explanation of human institutions in the observed facts of their origin and growth, without reference to metaphysical principles or moral preconceptions. Similarly, the ideals of the German universities, so far as accepted in New England and unaccompanied by the compulsions of German metaphysics, meant little more than a multiplication of erudite details accumulated with the indiscriminate enthusiasm of an antiquarian, or a romantic immersion in the lives and interests of a more glamorous era; whereas to Holmes, the value of his research was that it was directed to a crucial point and the purpose of his studies of the past was to gain a better understanding of the present.

How far this essentially modern scientific and empirical attitude on the part of Holmes differed from the point of view of the cultural environment in which he was born and educated, may be illustrated by the fact that in I860 Ticknor and Fields, the leading Boston publishing house previously mentioned, declined the opportunity to publish Herbert Spencer's Essays on Education, and thus the International Scientific Series, which included writings of Darwin, Bagehot, Buckle, Helmholtz, Huxley, Lecky, and Tyndall, had to find sponsors elsewhere.

But it should not be inferred from this that Holmes was not well regarded in Boston. On the contrary, he was recognized as an eminent legal scholar. In I882, the year following the publication of his Common Law, he was offered an appointment to the Supreme Court of Massachusetts. Earlier in that year he had been appointed a full professor of Harvard Law School. He was thus required to make a choice between the two careers, and it was not altogether easy. But again, possibly moved by the same considerations that directed him to the profession of law rather than the pursuit of formal philosophy, he chose the position that promised the fullest exercise of his faculties. For, some years later, after stating that he doubted whether there was "any more exalted form of life than a great abstract thinker," he went on to say: "But after all the place for a man 
who is complete in all his powers is in the fight. The professor, the man of letters, gives up one-half of life that his protected talent may grow and flower in peace."8

The next twenty years were uneventfully spent in the routine duties of a state supreme court justice. Holmes contined to live in Boston, where most of the court work was done, except for the occasions when he went on circuit. The only change that occurred during that period was his appointment as Chief Justice in I899, after seventeen years of service as an associate justice.

There are those who believe that the period of service on the state court added little or nothing to Holmes' stature. It is also true that Holmes himself, shortly after he was appointed Chief Justice of the Massachusetts Court and was close to completing twenty years on the bench, said that in checking his records he found he had written a thousand opinions for the court: "A thousand cases, many of them upon trifling or transitory matters, to represent nearly half a lifetime! A thousand cases, when one would have liked to study to the bottom and say his say on every question which the law ever has presented, and then to go on and invent new problems which should be the test of doctrine, and then to generalize it all and write it in continuous, logical, philosophic exposition. ...."

Yet Holmes' mind then, as always during his life, was not idle, nor were his interests flagging. His appetite for reading continued to be voracious, including not only the subjects of legal research which he had cultivated in preparing his Common Law but also, and more particularly, philosophy history, economics, and general literature. In addition, he made some contributions of his own to legal periodicals during that period, although the occasions were few and largely confined to rounding out the exposition of the theories he had previously expressed.

But the most important aspects of Holmes' twenty years on the state court bench, apart from the value of his services in the administration of justice in Massachusetts, were the gradual maturing of his philosophy and the opportunities his judicial position gave him to test and apply the theories he had advanced in his Common Law.

After all, he was only forty-one years old when he became a judge, and the last fifteen of those years had been spent in a somewhat, if not altogether, cloistered existence. Some period of time, less preoccupied, was necessary to round out the fullness of his character, knowledge, and judgment. And some period also was required to perfect that power of expres-

${ }^{8}$ Holmes, Collected Legal Papers 224 (rg20).

9 Tbid., at 245. 
sion, that precision of phrase, that combination of compact wit, poetry, and profundity which characterized the utterances of his later life.

Thus in the occasional speeches that Holmes made at academic and bar association functions, and in such of his correspondence during that period as has been thus far published, we find indications that his philosophy was now taking its final, settled form. It is mostly from that period that the quotations heretofore made have been taken, and perhaps at this point a few more are appropriate.

As illustrative of the degree to which Holmes consciously sought independence of the restrictions of the past and of the limitations of his own environment, we find these:

The past gives us our vocabulary and fixes the limits of our imagination; we cannot get away from it. ... But the present has the right to govern itself so far as it can; and it ought always to be remembered that historic continuity with the past is not a duty, it is only a necessity..$^{\circ}$

A man is bound to be parochial in his practice- to give his life, and if necessary his death, for the place where he has his roots. But his thinking should be cosmopolitan and detached. He should be able to criticise what he reveres and loves. ${ }^{x x}$

As indicative of the two dominant features of his personal philosophy, the following are as revealing as any:

Life is action, the use of one's powers. As to use them to their height is our joy and duty, so it is the one end that justifies itself. ... . Life is an end in itself, and the only question whether it is worth living is whether you have enough of it. ${ }^{\mathrm{xz}}$

I care not very much for the form [of religious or philosophic belief a man has] if in some way he has learned that he cannot set himself over against the universe as a rival god, to criticise it or to shake his fist, at the skies, but that his meaning is its meaning, his only worth is as a part of it, as a humble instrument of the universal power. It seems to me that this is the key to intellectual salvation, as the key to happiness is to accept a like faith in one's heart, and to be not merely a necessary but a willing instrument in working out the inscrutable end. ${ }^{x 3}$

But Holmes was not devoting his thoughts solely to defining his personal philosophy, although, of course, it was an integral part of his attitude towards law and the function of the judiciary. As a judge, during those twenty years on the state bench he was not only showing his scholarship and judicial ability, he was also showing his recognition of the social changes that were challenging the settled habits of legal thought. And this he was doing in a way that manifested the essence of the harmonious blend of his personal and his judicial philosophy.

For in one sense he was not sympathetic with the apostles of social regeneration through economic manipulation. As he put it once, he was not
ro Ibid., at r39.
23 Ibid., at $247-48$.
II Mbid., at 269.
${ }^{2} 3$ Ibid., at $\mathrm{I} 66$. 
"one of the gents who believed in the upward and onward" to any great extent. More specifically, he said, on another occasion:

$I$ have no belief in panaceas and almost none in sudden ruin. I believe with Montesquieu that if the chance of a battle-I may add, the passage of a law-has ruined a state, there was a general cause at work that made the state ready to perish by a single battle or a law. Hence I am not interested one way or another in the nostrums now so strenuously urged. $x^{4}$

But in another sense he was hospitable to new ideas and new legislation. In the first place, although he held to his own basic convictions consistently and tenaciously, he regarded them as personal compulsions, and not as ultimate truths necessarily shared by others or to be imposed on them. In the second place, he had a view, not so frequently expressed, but clearly influencing his acceptance of legislation which appeared to be in response to strong public demand, that the test of a good government is its "correspondence to the actual equilibrium of force in the community-that is, conformity to the wishes of the dominant power. Of course," he added, "such conformity may lead to destruction, and it is desirable that the dominant power should be wise. But wise or not, the proximate test of a good government is that the dominant power has its way." 25 And, finally, he sincerely believed in freedom of speech and freedom of experiment as the best assurance of reaching the ultimate good, whether in government or in ideas.

Those views reflected themselves to some degree in opinions Holmes rendered while on the Massachusetts bench. In particular, they showed in his dissents against the prevailing views of his brethren, when they held that certain state legislation in the direction of public ownership was unconstitutional and also when they sustained injunctions against picketing and boycotting by labor unions in furtherance of their members' interests.

This general attitude of Holmes towards the current social questions, together with other more recondite political considerations, moved President Theodore Roosevelt to appoint him to the Supreme Court of the United States in December, I902. Holmes at the time was sixty-one years old, and he felt that he was approaching the end of his life, but in keeping with his character he willingly accepted a call to a position which promised a wider use and fuller enjoyment of his powers. As events turned out, he was to serve on the Supreme Court of the United States for nearly thirty years, or more than a fifth of the entire period of its existence, and he was thus to participate in more than a third of the decisions which had been rendered by that court since its establishment.

$x_{4}$ Ibid., at 295.

15 Ibid., at 258 . 
And Holmes utilized to the full the opportunity thus given him to test and apply on a larger scale, and under more exacting conditions, the philosophy of law and government which had already become an outstanding feature of his thought and character. Here again, as when he made his first studies of law, and as when he later served on the Massachusetts court, neither the influence of others nor the stress of circumstances prevented him from reaching or expressing his own conclusions.

It is not necessary here to give an extended analysis or review of the judicial utterances of Holmes during his years on the United States Supreme Court. They are a part of our current history, and their ultimate influence upon the future of this country is still incapable of prediction. But it is possible to show by a few extracts their consistency with his settled character and philosophy.

$\mathrm{He}$ was, as previously indicated, more than dubious of the wisdom or efficacy of legislation designed to effect moral or economic betterment. Yet he said:

While the courts must exercise a judgment of their own, it by no means is true that every law is void which may seem to the judges who pass upon it excessive, unsuited to its ostensible end, or based upon conceptions of morality with which they disagree. Considerable latitude must be allowed for differences of view as well as for possible peculiar conditions which this court can know but imperfectly, if at all. Otherwise a constitution, instead of embodying only relatively fundamental rules of right, as generally understood by all English-speaking communities, would become the partisan of a particular set of ethical or economical opinions, which by no means are held semper ubique et ab omnibus. ${ }^{26}$

His own political and economic views were those of the laissez faire school. Yet when the majority of the court used that point of view to reject as unconstitutional legislation limiting the permissible hours of labor, Holmes stated in his dissent:

This case is decided upon an economic theory which a large part of the country does not entertain. If it were a question whether I agreed with that theory, I should desire to study it further and long before making up my mind. But I do not conceive that to be my duty, because I strongly believe that my agreement or disagreement has nothing to do with the right of a majority to embody their opinions in law..... The Fourteenth Amendment does not enact Mr. Herbert Spencer's Social Statics. ${ }^{x 7}$

He had no enthusiasm for the labor union movement; yet in dissenting from an opinion striking down state legislation in support of that movement, he said:

In present conditions a workman not unnaturally may believe that only by belonging to a union can he secure a contract that shall be fair to him..... If that belief,

${ }^{26}$ Otis v. Parker, 187 U.S. 606, 608-9 (rgo3).

${ }^{17}$ Lochner v. New York, I98 U.S. 45, 75 (r905). 
whether right or wrong, may be held by a reasonable man, it seems to me that it may be enforced by law in order to establish the equality of position between the parties in which liberty of contract begins. Whether in the long gun it is wise for the workingman to enact legislation of this sort is not my concern, but I am strongly of opinion that there is nothing in the Constitution of the United States to prevent it. . . . ${ }^{88}$

His own fundamental philosophy was reflected even more clearly in his opinions in favor of freedom of speech.

Thus, although he abhorred the ultimate system that Communism envisioned, he said in support of the right to preach its doctrines:

Persecution for the expression of opinions seems to me perfectly logical. If you have no doubt of your premises or your power and want a certain result with all your heart you naturally express your wishes in law and sweep away all opposition. .... But when men have realized that time has upset many fighting faiths, they may come to believe even more than they believe the very foundations of their own conduct that the ultimate good desired is better teached by free trade in ideas-that the best test of truth is the power of the thought to get itself accepted in the competition of the market, and that truth is the only ground upon which their wishes safely can be carried out. That at any rate is the theory of our Constitution. It is an experiment, as all life is an experiment. Every year if not every day we have to wager our salvation upon some prophecy based upon imperfect knowledge. While that experiment is part of our system I think that we should be eternally vigilant against attempts to check the expression of opinions that we loathe and believe to be fraught with death, unless they so imminently threaten immediate interference with the lawful and pressing purposes of the law that an immediate check is required to save the country. ${ }^{29}$

But a voice, however eloquent, cannot speak forever, and no human, however vital, can escape the burdens of mortality. At the age of ninety, Holmes was still active on the court, accepting and performing his full share of judicial duties and still enjoying to the utmost the interest and excitements of life. A year afterwards, on sensing the first sign of the weakening of his faculties, he resigned. Three years later, on March 6, I935, he died; and on the day he would have reached his ninety-fourth birthday he was buried, with military honors, in the National Cemetery at Arlington, Virginia. Thus in death, as in life, this son of New England belongs to us all, and, similarly, the ideals which he advocated are not wholly to be identified by the year and place of his birth, but are, in larger measure, a timeless gift to humanity.

${ }^{8}$ Coppage v. Kansas, 236 U.S. I, 26-27 (Ig15).

${ }^{19}$ Abrams v. United States, 250 U.S. 616, 630 (I9I9). 